\title{
Coastal and Marine Resource Policies and the Loss of Ethnic Identity of the Bajo Tribe
}

\author{
Muhammad Obie \\ Department of Sociology, \\ State Islamic University of Sultan Amai Gorontalo, \\ Indonesia \\ Lahaji \\ Faculty of Sharia, \\ State Islamic University of Sultan Amai Gorontalo, \\ Indonesia
}

Doi: 10.36941/ajis-2020-0050

\section{Abstract}

The Bajo Tribe constructs themselves as part of their environment; their identity is bound to their relationship with coastal and marine resources. They lived and owned the coastal and marine resources in Tomini Bay since the 18oos; however, it shifted when the state set conservation and concession policies since the 1980s. This research analyzed the coastal and marine resource policies and its impact on the ethnic identity of the Bajo tribe. The researchers applied the historical sociology approach and collected data through observation, interviews, and documentation methods. The result showed that the state policies regarding coastal and marine resources, which followed by the resettlement program to the land, caused the customary institution of the Bajo Tribe removed from its cultural roots. Conservation policy resulted in the territorializing of coastal and marine areas. Meanwhile, the concession policy of forest management permit and cultivation right on land had caused damage in coastal and marine resources due to overexploitation. These policies cause the loss of ethnic identity of the Bajo Tribe due to closed access and destruction of coastal and marine resources.

Keywords: Coastal and marine resources, ethnic identity, Bajo tribe, Tomini bay, conservation; concession

\section{Introduction}

The coastal area has strategic meaning due to the potential of natural resources and its wealthy environmental services. The richness of the resources attracted various parties to utilize them, and various institutions have tried to regulate the utilization (Yulianda et al., 2010; Deni Dj., 2009). Some parties who have the interest to manage the resource often clash and cause a conflict (Zulkifli et al., 2019; Obie et al., 2014; Camus, 2019; Rechciński et al., 2019). The coastal area can be understood as a meeting point of various interests from the state, corporation, and society in utilizing resources contained therein. Different perceptions and interests have triggered an overlap of authority and conflict of interest in the implementation of the regulation of coastal area management. This kind of situation puts local communities losing their ability to utilize the coastal and marine environment 
due to government policies that open up access to the broadest possible for corporate owners (Camus, 2019).

The confusion in ownership and control of coastal resources has caused law uncertainty in the management of the coastal area (Bromley \& Cernea, 1989). Local communities consider that coastal resources have no owner; thus, anyone can access and use the potential (open access). In various coastal areas, local communities consider that their surrounding resources are their common property based on the customary law that existed long before the establishment of the Republic of Indonesia (Idris et al., 2007). Moreover, in article 33 of 1945 Constitution, Law No. 5, 1983 on Exclusive Economic Zone (EEZ), Law No. 1, 1973 on the Continental Shelf of Indonesia, Law No. 6, 1996 on Indonesian Waters, Law No. 17, 1985 on the Validation of the United Nations Convention on the Law of the Sea in 1982 and Law No. 32, 1999 revised with Law No. 32, 2004 on Regional Government clearly stated that the state controls coastal and marine resources. The closure of coastal and marine areas by the government has resulted in conflicts with local communities (Beuret et al., 2019).

The state, with its authority, has a dual function, namely as a protector, as well as the user of the natural resources (Bryant \& Bailey, 1997). The protecting area has become one of the factors in the occurrence of social conflict (Rechciński et al., 2019). The conflict occurred because the forest edge communities maintained their livelihood base from forest areas (Obie et al., 2019). The entry of various state policies in the coastal area of Tomini Bay collided with the existence of customary institutions of the Bajo Tribe. The Bajo Tribe constructed themselves as part of their natural environment and viewed nature as their primary livelihood. Bajo Tribe treated nature wisely and exploited it merely for fulfilling their life necessities. The tribe's view is in contrast with the state's view toward natural resources, including coastal and marine resources. The state views the coastal and marine resources in Tomini Bay as an economic base; thus, it should be exploited to improve the economic value. The state, then, gives the concession to the corporation to exploit the coastal and marine resources to gain economic profit. It negated the existence of the Bajo Tribe and their customary institution. In addition to the economic base, the state also views the coastal and marine resources in Tomini Bay as a protected site and should be free from human intervention, including the Bajo Tribe, who had settled in Tomini Bay long before. Both views of the state have equally positioned the tribe to leave the area.

The Bajo Tribe, in this case, experiences two-dimensional pressures, structural and poststructural dimensions. The structural dimension is in the form of imbalance in power relations regarding the management of natural resources that dominated by capitalist corporate and poststructural dimensions in the form of the limitation and the loss of access for the Bajo Tribe toward their primary livelihood (Forsyth, 2003). The entry of capitalist corporations in the coastal area of Tomini Bay causes the diminishing or even the loss of ability and right of access of the Bajo Tribe (Ribot \& Peluso, 2003). Meanwhile, if ownership is classified based on the concept of the bundle of rights, the entry of coastal area utilization and conservation had closed the ownership of the Bajo Tribe from the proprietor who has the access, utilization, management and exclusion (Ostrom \& Schlager, 1996).

The issue becomes the cause of environmental damage called the tragedy of enclosure, which is a tragedy due to the domination of state and private that results in the limitation of access for society toward the utilization and management of resources (Bryant \& Bailey, 1997). The closed of access of the Bajo Tribe toward coastal and marine resources, which becomes their primary of livelihood from generations, had created a fisherman without the sea ( $\mathrm{Li}, 2012)$. Meanwhile, the ownership of land and other natural resources is a crucial factor for the indigenous people. Land and natural resources are part of the vital identity for indigenous people that mark their existence (Lund, 2011). The closed access and destruction of coastal and marine resources implicated the loss of ethnic identity of the Bajo Tribe. 


\section{Research Method}

This study applied the historical sociology strategy. The study of the loss of ethnic identity in the Bajo Tribe as the implication of the policy of coastal and marine resources management was a symptom of social process in a certain period. The type of data used as analysis materials was primary data gained from the actors as the main informant through in-depth interviews and passive participation observation. In order to complete the primary data, secondary data was needed through the study of documents such as previous research results, laws, and government regulation. Also, data analysis was conducted through a qualitative approach. Data analysis (Sugiyono, 2009) was performed simultaneously during data collection, and after completion of data collection within a specified period.

\section{State Policies on Coastal and Marine Resources in Tomini Bay}

The Bajo Tribe had been living in Tomini Bay since the 18oos. The area then was officially stated as the colony of the Bajo Tribe by the Dutch Colonial Government in 1901, although at that time, they still lived on boats (Zacot, 2008). The existence of control of the Bajo Tribe toward coastal and marine resources in Tomini Bay started to be disturbed since the New Order Government of Indonesia followed economic pro-strategy with the issuance of Law No. 1, 1967 on Foreign Investment and Law No. 5, 1967 on Forestry and one year later Law No. 6, 1968, on Domestic Investment. The three laws indicated the state signal to raise overseas orientations. It means that the state had opened access to the highest possible extent for both foreign and domestic investors to manage natural resources. Tomini Bay, with its significant natural resource potentials, was not an exception. The economic investment marked its influence in the coastal area of Tomini Bay since 1977 when timber company and fishpond farms entered the area after gaining a concession license from the central government in the form of forest management permit and cultivation right on the land.

The entry of big companies holding the forest management permit and cultivation right on land at the coastal area of Tomini Bay gave terrible impact for the Bajo Tribe community with the closing of their access to gain benefit from the management of coastal and marine resources, which become their primary livelihood for generations (Obie, 2015). Meanwhile, in order to protect the area, the state issued a policy of the determination of the conservation area. The issuance of the Decree of Minister of Forestry No. 250/Kpts-II/1984 on December 20, 1984, set mangrove forest at the coastal area of Tomini Bay as a conservation forest had limited the space of the Bajo Tribe to gain benefit from the area. Furthermore, the fulfillment of the livelihood of the Bajo Tribe was in the vulnerable position because the regulation had insulted the existence of the Bajo Tribe in collecting forest products at the coastal area as their primary livelihood (Obie et al., 2014). The state policy that gave concession permits to the corporation as well as set the mangrove forest at the coastal area of Tomini Bay as a conservation area affected the resettlement of the Bajo Tribe who lived in the area.

The first resettlement of the Bajo Tribe community was started from the entry of timber company, limited liability company of Mara Bunta Timber, at Tomini Bay in 1977. Due to the entry of the company, the Bajo Tribe, who lived in the coastal area, was forcibly displaced and directed to join other settlements of the Bajo Tribe in the eastern part not very far from the area. Their housing was evicted, and the sea area where they put their bagang (a structure built for traditional fishing located in the middle of the sea) was taken over by the company as their passing way for loading and uploading operational ships. The Bajo Tribe rejected the displacement; however, due to the pressure and intervention from the village government and the power escort from the police, they withdrew their intention to stay. Further, the Bajo Tribe who lived above the sea faced pressure from the government to join the resettlement program on the mainland.

The program gained strong rejection from the Bajo Tribe; thus, it could not be implemented. It was because the representative of the Bajo Tribe met directly with local and central governments, in this case, the Advisor of the Minister of Environment and Population in Jakarta, to explain the 
reasons for rejection. According to the Bajo Tribe, the resettlement program to mainland area was unreasonable program viewed from various aspects: human, economy, and materials (Zacot, 2008). Various ways conducted by the state to convince the Bajo Tribe to agree with the program. Through village elites, the state spread propaganda to confront the Bajo Tribe if they keep living above the sea. The Social Department of the Republic of Indonesia that became the leading sector in the resettlement program, formed Field Social Workers. Local people were recruited for both elements and became the determinant for the programs initiated by the Social Department.

The field social workers had a role in giving counseling and organizing the Bajo to accept the resettlement program. The resettlement program of Bajo Tribe in Tomini Bay finally succeeded for the first time in 1984/1985, although not everyone joined the program. Along with the implementation of the resettlement program, the village hall was moved to the mainland, but when reallocation of the village was conducted in 2005, the village hall of Torosiaje was returned to the sea, and Torosiaje Jaya village hall was still in the mainland. Finally, the Bajo Tribe experiences five phases of resettlement: the first phase in 1984/1985 was resettled 125 family heads; second phase in 1985/1986 with 50 family heads; third phase in 1995/1996 with 50 family heads; fourth phase in 1996/1997 with 50 family heads, and fifth phase in 1997/1998 with 84 family heads. During the resettlement process, around 40 family heads secretly left their homes in the mainland and back to the sea. Meanwhile, the Bajo Tribe, who still lived on the sea surface until now, was 338 family heads (Obie et al., 2015). Due to the resettlement program, the Bajo Tribe in Tomini Bay is divided into two communities known as Bajo Laut and Bajo Darat. Bajo Laut is a designation for the Bajo who still lived on the sea, and Bajo Darat is the Bajo who joined the resettlement program and lived in the mainland.

\section{Ownership of Coastal and Marine Resources}

Land use system and land control by the indigenous people had drastically changed due to the practice of state policy related to the control of the state over the forest since the colonial days. The state control over the forest had been taken place up until now through territorializing its control over the forest. Territorializing is understood as a process made by the state to control people and their activities by putting a line around the geographic space, prevent certain people from entering the space, and allowing or prohibiting activities within the boundaries of the space (Vandergeest, 1996). Besides, territorializing of the control over the forest is a way where the state power over forest area prevailed within forest area boundaries determined politically by the state; the state power over forest area is prevailed to control people in utilizing resources within those boundaries (Vandergeets \& Peluso, 1995; in Siscawati, 2014).

The state control over forest either through the determination of state forest area or give concession to the corporation had denied the existence of indigenous people and other local communities. In other words, the state considers the indigenous people and other local communities as invisible because they are not considered as the owner of their indigenous territories (Rachman \& Siscawati, 2014). In contrast, the administrating of ownership rights and access right toward fundamental rights is the admission requirement of indigenous people (Lund, 2011). Both views clarify the marginalization of the ethnic identity of the Bajo Tribe as indigenous people by the state.

The Bajo Tribe, who previously utilizes coastal and marine resources in Tomini Bay, faced livelihood vulnerability since the state and corporation take over the management of the resources. It happens because of the differences of interest in considering the existing resources. The Bajo Tribe considers the coastal and marine resources in Tomini Bay as their primary livelihood (Obie et al., 2020) since they live and take marine products there. The Bajo Tribe lives together with nature and exploits them as necessary and maintains to preserve them, while the state and its interest to protect and improve the economy treats the coastal and marine resources in Tomini Bay as a double-edged knife. On the one hand, the state issued conservation policy that the existing resources should be kept from human intervention, but on the other hand, the state considers the natural resources as economic sources thus exploitation through forest management permit, cultivation right on land and 
logging permit for a corporation is a necessity.

Both policies of protection and exploitation of coastal and marine resources had crashed the primary livelihood of the Bajo Tribe. Along with the determination of the coastal area of Tomini Bay as a conservation forest, the livelihood of the Bajo Tribe sourced from the area disturbed due to the related regulation. The Bajo Tribe is prohibited from accessing the area, although they had been staying there long before the issuance of the laws. They no longer have the freedom to take wood from the mangrove area for firewood and building materials since the decision regarding conservation forest was issued. Finally, they had to spend much money to buy timber prepared by the people in the mainland to build their houses on the sea. As stipulated in the Government Regulation No. 28, 1985 on Forest Protection article nine that except for forest officials or someone due to his/her job or interest is allowed to be in the forest area, anyone is prohibited to carry tools for cutting down, and splitting trees in the forest area (paragraph one); anyone is prohibited from cutting down trees in the forest without permission from the authorized officials (paragraph two); anyone is prohibited from taking/collecting other forest products without permission from the authorized officials (paragraph three).

It can be seen that the utilization of forest products was closed. The explanation of the article stated clearly that the people because of their homes in or have to go through the forest are prohibited from cutting down and to bring cutting tools. They are also prohibited from collecting forest products such as leaves, firewood, rattan, charcoal, etcetera. The regulation created a conflict for the Bajo Tribe, who were losing their primary livelihood sourced from the area. Also, the issuance of the state policy on forest utilization in the form of concession rights for private sectors impacts the vulnerability of the primary livelihood of the Bajo Tribe. As stipulated in the Governmental Regulation No. 21, 1970 on natural forest management permit and cultivation right on land article six that the rights of indigenous people and its members to collect forest products based on the existing customary law need to straighten up for its implementation so that it will not disturb the operation of forest management (paragraph one). The implementation, as stated in paragraph one of this article, needs to have permission from the holder of the original forest management permit that permits the implementation of the rights, as stated in paragraph one of this article. It is arranged with an order as the result of discussion between the rights holder and customary law society with guidance and supervision from regional department of forestry (paragraph two); For general safety, in the forest area that is being worked on for forest exploitation, the implementation of people right to collect forest product is frozen (paragraph three).

The regulation negates the existence of indigenous people in collecting forest product as their primary livelihood and give full authority to the corporation holding natural forest management permit to exploit the forest. In Tomini Bay, the entry of the corporation through forest management permit and cultivation right on land had disturbed the primary livelihood of the Bajo Tribe. The operation of a timber company, limited liability company of Mara Bunta Timber, at the coastal area of Tomini Bay in 1977 brought harsh reality for the Bajo Tribe, who lived in the area and looked for marine products by fishing and set bagang. The Bajo Tribe was prohibited from living and looking for marine products in the coastal area; thus, they had to leave their livelihood activities.

The area had abundant fish potential; thus, when limited liability company of Mara Bunta Timber closed their operational and continued by limited liability company of Wenang Sakti, the Bajo Tribe returned to the area to look for marine products. The Bajo tribe utilized the transition time from limited liability company of Mara Bunta Timber to limited liability company of Wenang Sakti by set back their bagang and conducted the fishing activity in the area. Meanwhile, the entry of fishpond concession initiated by the Regional Government of Gorontalo Regency also created the vulnerability of the primary livelihood of the Bajo Tribe. Land clearing for salt ponds in 1977 initiated by the Government of Gorontalo Regency had caused the clearing of 70 hectares of mangrove forest. The salt ponds were extended along with the issuance of the Decree of Governor of the First Level Regional Head of North Sulawesi No. 200/1996 on the reserve of land for the transmigration location of fishpond pattern in Gorontalo Regency of 12,752 hectares. In the next progress, in the 1980s, the 
salt ponds gradually shifted the function into shrimp and milkfish ponds. The shifting inland function aggravated the destruction of mangrove resources in the coastal area of Tomini Bay.

The Bajo Tribe, who relied on coastal areas, understood that the good and bad of coastal environment would have a direct impact on their life. The future of the Bajo Tribe, who rely on coastal and marine resources is threatened since the availability of coastal and marine resources in their surrounding neighborhood decrease in the number of population and endangered. It is undeniable that ecological change impacted the social and economic of Bajo Tribe's fishermen. It is in line with a statement from (Badjeck et al., 2010) that ecological change occurred in the sea resulted in a change in the availability of fishery products as the principal capital of fishers. Also, it could influence fisherman's income and, in turn, the increase in the cost of accessing resources. Adger and Brooks (2003) stated that the loss of the mangrove ecosystem eroded the available livelihood of local fishers.

The destruction of coastal and marine resources by corporation activities along with the loss of access in the fulfillment of fundamental rights of the Bajo Tribe as well as the territorializing of the area in conservation that led to the resettlement of the Bajo Tribe to the mainland through resettlement program had degraded the ethnic identity of the tribe as indigenous people. The Bajo Tribe is discarded either in its position as a tribe entity or in its existence as part of a modern nationstate. As a tribe entity, the Bajo Tribe is uprooted from its cultural root as the implication of resettlement policy to the mainland from their previous settlement on the sea.

\section{Customary Institution and Ethnic Identity of the Bajo Tribe}

Due to the state policy on the management of coastal and marine resources that encouraged the entry of state and private institutions, the customary institution of the Bajo Tribe is marginalized. The customary institution is based on hereditary cultural and traditional values; while, state institution is based on laws. A private institution, on the other hand, enters through the state policy in order to improve the economy. Historically, before the entry of state and private institutions, customary institutions have a role in the management of coastal and marine resources in Tomini Bay. The Bajo Tribe takes the coastal and marine areas as their base livelihood, so settle and exploit them on a limited basis. Starting from the simple understanding that coastal and marine resources are part of the life of the Bajo Tribe; thus, there is a harmonious relationship between the Bajo Tribe and their environment.

The interaction of customary institutions of the Bajo Tribe with state and private institutions is imbalanced and influenced by power penetration and the marginalization of the Bajo Tribe's position. The interaction is unavoidably caused the disintegration of customary institution of the Bajo Tribe. The disintegration is started from the system level, the state-issued laws that systematically negated the authority of customary institutions in managing the coastal and marine resources. The disintegration of customary institutions of the Bajo Tribe also occurred at organizational and individual levels. The entry of state and private institutions harms the customary institution, directly or indirectly. It is related to the dominating decision-making procedure, the imbalanced resource control, and different institutional culture. The entry of state and private institutions has caused social upheavals due to the loss of access toward coastal and marine resources that became the Bajo Tribe's primary livelihood, and in turn, it has implications for the disintegration of cultural and traditional values owned by the customary institution of the Bajo Tribe.

Institutionally, the Bajo Tribe in the coastal area of Tomini Bay is led by the head of the village and the head of customs. The head of customs is assisted by six members of the traditional council and formed a group called Pupukana. Even though the traditional council had the rights to fine the head of the village if he/she broke the customs, they could not get involved with the village affairs. On the contrary, the head of the village could interfere in common issues (Zacot, 2008). A particular case is related to the treatment for sick people using traditional ceremonies, and the traditional council is assisted with duata. Duata institution is part of the customary institution of the Bajo Tribe 
that especially manages the traditional rituals and medication.

The traditional rituals and medication conducted by the institution could not be separated from the harmonious relationship between the Bajo Tribe and their natural resources. It means that it could not be separated from the coastal and marine resources. It is because the Bajo people believe that every ecosystem in the coastal area and the sea is guarded by the spirits. Mangrove ecosystem is guarded by a spirit that lives in the area; the coral reefs area is guarded by a spirit in the area; the seagrass ecosystem is guarded by a spirit of the area as well as the sea that guarded by a spirit in the sea. The Bajo people believe that if the spirits in the ecosystem are being disturbed, the spirits will show their anger. Therefore, the Bajo people treat the ecosystem with caution.

The Bajo people believe that all diseases occurred in their community are from the spirits that guard the ecosystems. Therefore, whenever one of them is sick, duata would gather to identify the origin of the disease. They believe that the destruction of the coastal ecosystem is a disaster for their community. In order to avoid the wrath of the spirits that guards the ecosystems, duata often conduct traditional ceremonies to ward of diseases. They feel that the environment is part of them. They often conduct traditional ceremonies related to the environment.

The disintegration process of duata institution occurred through the laws that implemented with conservation and repressive policy of resettlement and the entry of corporations that destroyed coastal and marine resources. With the establishment of the mangrove area at the coastal area of Tomini Bay as a conservation forest, it negated the meaning of duata institution over the mangrove and other coastal resources. Meanwhile, the resettlement program that forcibly moved the Bajo Tribe to the mainland had removed duata institution from its cultural root. Duata could not be separated from coastal and marine resources, while the resettlement program had removed the values of duata for the Bajo Tribe who live in the mainland.

The disintegration process of duata institution also occurred along with the destruction of mangrove and other coastal resources. The private institution that conducted land clearing for fishponds by destroying the mangrove area had weakened the moral values that existed in duata institution. It is concomitant with the belief of the Bajo people institutionalized in duata that the spirits inhabited mangrove forests and all coastal and marine resources. The belief was weakened along with the destruction of mangrove that converted into fish ponds. The weakening belief of the Bajo people toward the guardian spirits of the resources weakened the existence of duata institution. In the end, the philosophy of living harmoniously with nature increasingly shifted to natural exploitation for the fulfillment of life necessities. The Bajo people then cut mangrove trees to sell to people who lived in the mainland as firewood, and they even went fishing using explosives.

\section{Conclusion}

The Bajo Tribe, who was known as the sea nomads, had been around the Archipelago long before the recognition of the sea as a unity in the Republic of Indonesia. The Bajo Tribe had been around Tomini Bay since the 1800 s and set as a community by the Dutch Colonial Government in 1901. The Bajo Tribe constructs themselves as part of their environment; therefore, the social system is related to its relationship with coastal and marine resources. Hence, the ownership of coastal and marine resources for the Bajo Tribe is absolute. The ownership becomes the base of the Bajo Tribe identity in the coastal and marine area of Tomini Bay.

The ownership of coastal and marine resources of the Bajo Tribe is disturbed since the state set a policy of conservation area as well as an economic investment. Both policies had robbed the owner of the Bajo Tribe toward the coastal and marine resources in Tomini Bay. Determination of conservation area results in the area territorializing that closed the access of the Bajo Tribe to gain benefit from the coastal and marine area. In the meantime, economic investment policy that gives concession rights to capitalist companies in the form of forest management permit and cultivation rights on land has destroyed coastal and marine resources due to excessive exploitation. Those state policies had made the Bajo Tribe face pressure from the resettlement program to the mainland that 
required them to leave their settlement on the sea.

The closed access and destruction of coastal and marine resources due to the state policies results in the loss of ethnic identity of the Bajo Tribe as the sea people that differentiate them from the land people. That is because the Bajo Tribe uprooted from their cultural roots at sea.

\section{References}

Adger, N., \& Brooks, N. (2003). Does Global Environmental Change Cause Vulnerability to Disaster? in Pelling, M. (ed.) Natural Disasters and Development in a Globalising World. London: Routledge.

Badjeck, M. C., Allison, E. H., Halls, A. S., \& Dulvy, A. S. (2010). Impacts of climate variability and change on fishery-based livelihood. Journal of Marine Policy, 34, 375-383.

Beureut, J. E., Cadoret, A., Pothin, K., Barnay, A. S., Bihan, O. L., \& Allouet, M. A. S. (2019). Understanding and Valuing Conflicts in Marine Protected Areas: The Best Way to Develop Innovation? Aquatic Conserv: Mar Freshw Ecosyst, 29(S2), 212-222

Bromley, D. W., \& Cernea, M. M. (1989). The Management of Common Property Natural Resources: Some Conceptual and Operational Fallacies. World Bank Discussion Papers (57). Washington, D. C.: The World Bank.

Bryant, R. L., \& Bailey, S. (1997). Third World Political Ecology. New York: Routledge.

Camus, Pablo, (2019), Environmental Conflict and Exploitation in the Coastal Areas of Chile. Available: https://www.researchgate.net/publication/335526522_Environmental_Conflict_andExploitation_in_the_Coa stal_Areas_of_Chile (February 02, 2020)

Deni Dj., R. (2009). Bahari Nusantara untuk Kesejahteraan Masyarakat dan Ketahanan Nasional. Jakarta: MSCC

Forsyth, T. (2003). Critical Political Ecology: The Politics of Environmental Science. London: Routledge.

Idris, I., Ginting, S. P., \& Budiman. (2007). Membangunkan Raksasa Ekonomi: Sebuah Kajian terhadap Perundangundangan Wilayah Pesisir dan Pulau-Pulau Kecil. Bogor: Penerbit Buku Ilmiah Populer.

Li, T. M. (2012). The Will to Improve: Perencanaan, Kekuasaan, dan Pembangunan di Indonesia. Translated into Bahasa Indonesia by Hery Santoso \& Pujo Semedi. Jakarta: Marjin Kiri.

Lund, Ch. (2011). Property and Citizenship: Conceptually Connecting Land Rights and Belonging in Africa. Africa Spectrum, 46(3), 71-75

Obie, M. (2015). Perampasan Hak Ulayat Pesisir dan Laut Komunitas Suku Bajo (Kasus Pengelolaan Sumber Daya Pesisir dan Laut di Teluk Tomini). Bogor: Disertasi Sekolah Pascasarjana IPB.

Obie, M., Soetarto, E., Sumarti, T., \& Saharuddin. (2014). Konflik Etnis di Pesisir Teluk Tomini: Tinjauan SosioEkologi Politik. Al-Tahrir, 14(2), 319-340.

Obie, M., Soetarto, E., Sumarti, T., \& Saharuddin. (2015). Sejarah Penguasaan Sumber Daya Pesisir dan Laut di Teluk Tomini. Paramita, 25(1), 73-87.

Obie, M., Yusuf, I. D. S., \& Sumai, S. (2019). Empowerment of Palm Sugar Peasants at the Forest Edge of Bogani Nani Wartabone National Park, Indonesia: A Study of Problems, Local Potentials, and Priority Ideas Towards Empowered Community. Environment and Natural Resources Research, 9(1), 77-9o

Obie, M., Pakaya, M., Mustakimah, \& Syilfi. (2020). Oil Palm Expansion and Livelihood Vulnerability on Rural Communities (A Case in Tomini Bay - Indonesia). Humanities \& Social Sciences Reviews, 8(1), o1-12.

Ostrom, E., \& Schlager, E. (1996). The Formation of Property Right, in Hanna, Susan, Carl Folke, Karl-Goran Maler (ed.), Right to Nature: Ecological, Economic, Cultural, and Political Principles of Institutions for the Environment. Washington, D.C.: Island Press, 130-132.

Rachman, N. F., \& Siscawati, M. (2014). Pengantar, Dalam Masyarakat Hukum Adat Adalah Penyandang Hak, Subjek Hukum, dan Pemilik Wilayah Adatnya. Yogyakarta: InsistPress.

Ribot, J. C., \& Peluso, N. L. (2003). A Theory of Access. Rural Sociology, 68(2), 153-181

Rechciński, M., Tusznio, J., \& Jurczak, M. G. (2019). Protected Area Conflicts: A State of the Art Review and a Proposed Integrated Conceptual Framework for Reclaiming the Role of Geography. Biodiversity and Conservation, 28, 2463-2498

Siscawati, M. (2014). Pengantar, Dalam Masyarakat Adat dan Perebutan Penguasaan Hutan. Wacana: Jurnal Transformasi Sosial, 33(XVI).

Sugiyono. (2009). Memahami Penelitian Kualitatif. Bandung: CV. Alfabeta.

Vandergeest, P. (1996). Property rights in protected areas: obstacles to community involvement as a solution in Thailand. Environmental Conservation, 23(03), 259-268

Yulianda, F., Fahrudin, A., Hutabarat, A. A., Harteti, S., Kusharjani, \& Kang, H. S. (2010). Pengelolaan Pesisir dan Laut Secara Terpadu. Bogor: Pusdiklat Kehutanan-Kemenhut RI 
Zacot, F. R. (2008). Orang Bajo Suku Pengembara Laut: Pengalaman Seorang Antropolog. Penerjemah Laure F.M., Pranoto I.B. Jakarta: Kepustakaan Populer Gramedia (KPG) bekerja sama dengan Ecolo Francaise d'ExtremeOrient dan Forum Jakarta-Paris.

Zulkifli, D., Suyasa, I. N., Maulita, M., Suharti, R., Rachmad, B., Dewi, I. J. P., Sabariyah, N., Muliyono, M., Triyono, H., Irawan, H., \& Herlambang, R. (2019). A Conflict Analysis of Management of Fishery Resources in Kalimantan, Indonesia. International Journal of Fisheries and Aqua Studies, 7(4), 78-85. 